\title{
An Investigation of Task and Ego Oriented Goals of the Students Majoring at the Faculty of Sport Sciences
}

\author{
Emre Belli
}

The Faculty of Sport Sciences, Atatürk University, Turkey

Copyright (C) 2015 by authors, all rights reserved. Authors agree that this article remains permanently open access under the terms of the Creative Commons Attribution License 4.0 International License

\begin{abstract}
The aim of this study is to explore the task and ego oriented goals of the students majoring at the Faculty of Sports Sciences at Ataturk University. For data collection, "The Task and Ego Orientation in Sport Questionnaire", which was developed by Duda (1) and adapted into Turkish by Toros and Yetim (2), was used in the current study to examine the task and ego oriented goals of students. This questionnaire was administered to a total of 375 students consisting of 224 male and 151 female students. For data analysis, SPSS statistical packet program was used for frequency analysis, and independent $t$-tests, one-way ANOVA and Tukey test were run to find out the source of the difference among different groups of participants. The results of the study showed that there was no statistically significant difference in terms of the comparison of the task and ego-oriented goals regarding the participants' gender $(p=, 332)$ whereas there was a significant difference between male and female students in terms of specifically ego-orientation especially in favor of female students $(p=, 003)$. Based on this result, female students were found to favor ego orientation to reach their goals much more than male students. Apart from that, the comparison of the participants' fields of study indicated that in terms of task-oriented goals, there was a statistically significant difference in favor of team sports $(p=, 025)$ and significant differences were revealed among participants from different fields of study in terms of ego-oriented goals especially in favor of individual sports $(\mathrm{p}=, 000)$. A number of implications for further research and education were suggested based on the results obtained from the analysis of the task and ego-oriented goals of male and female students majoring in different fields of study and departments.
\end{abstract}

Keywords Task-orientation, Ego-orientation, Physical Education, Sports

\section{Introduction}

In recent years, athletes' behavioral patterns that they perform to reach their goals have become one of the most significant fields of study in sport psychology. Athlete's individual performance on distinctive sport branch depends on many factors. Goal orientation has been considered as one of these factors. In that sense, goal orientation means that people are related to various goals or activities to gain sense of achievement resulting from reaching their goals. To obtain this sense of achievement, people are directed to various types of goals (Toros, 3). Keeping this definition in mind, the current study aims to contribute to the relevant literature with an attempt to reveal the target way that the individuals who are expected to serve Turkish sports pursue and their goal orientations.

According to theory of goal orientation, when people reach the goals, they also gain the feeling of achievement. The senses of achievement are obtained as a result of achieving the goals, and its value is evaluated according to the achievement by athletes. (Nicholls, Cheung, Lauer \& Pastashnick, 4). The feeling of success or failure depends on the athlete's goal orientation. Success determines the goal orientation compared to both a person and to others. In fact, goal orientation is one's objective which lets them to evaluate their own success.

The research on the theory of goal orientation showed that there are two independent ideas of success. These are called as task oriented goals and ego oriented goals. (Duda and Nicholls, 5; Nicholls et al., 4; Nicholls, Cobb, Yackel, Wood and, Wheatley, 6).

The first dimension of goal orientation is task-oriented goal. To be successful, athletes must work hard and must do their best. Success is in this process and pleasure is in action. Stephens and Bredemier (7) state that athletes who have high task orientation feel themselves skillful and are pleased to take part in sports. Athletes who have task orientation more than others consider that competition is a kind of chance to develop their skills. The better the competitors are, the more important it is to improve the individual skills for progress. Failure for the athletes with task-oriented goals is to perform less than optimal performance.

The second dimension of goal orientation, on the other hand, is ego-oriented goals. When ego-oriented athletes 
provide superiority to others, they gain the sense of success. For these athletes, to be qualified as "the best" is the pleasure, and they undeniably and constantly want to be the best (Toros \& Koruç, 8). According to Walling and Duda's (9) research, athletes who have high ego orientation become reluctant in competitions when they feel that they would not succeed. Such athletes think that winning or being superior is a superiority and they want to do anything to win even if it means breaking the rules (Duda, 10). Research shows that goal orientation associated with the ego leads to the lack of resistance, high anxiety levels, enjoying less, and becoming satisfied on sporting events. (Boyd, 11; Duda, 10; Duda and Chi, 12).

Considering the fact that the participants of the current research are majoring at Physical Training and Sports and they are expected to be future physical training teachers, sports management teachers, and trainers in sports community, having an insight into the task and ego oriented goals of these students is worth revealing in terms of individual and social concerns. In the light of these, the aim of this research is to investigate the task- and ego-oriented goals of the students studying at the Faculty of Sports Science at Atatürk University in terms of age, gender, field of study, department and grade.

\section{Methodology}

The aim of this study is to reveal the task- and ego-oriented goals of the students majoring at the Faculty of Sports Sciences at Atatürk University.

The population of the research is comprised of the students at the Faculty of Sports Sciences at Atatürk University and the sample for the current study consisted of a total of 375 students that included 224 male students and 151 female students. To select the participants who voluntarily would participate in the study, the participants were distributed a consent form and sign it before the distribution of the questionnaire if they voluntarily participated in the study.

For data collection, the questionnaire called "The Task and Ego Orientation in Sport Questionnaire" that was developed by Duda (1) and translated into Turkish by Toros and Yetim (2) was used to gather data. The reliability (Cronbach's Alpha) of the questionnaire was tested and the internal consistency of items in the questionnaire was found to be high in this context (0.88).

For data analysis, SPSS statistical packet program was used and the significance level was accepted as $(p<0,05)$

In the current research, frequency analysis was done for the analysis of demographic features of the students, independent $t$-tests were run to compare the students' task and ego oriented goals in terms of gender and fields of study, one-way ANOVA was carried out to find out the difference between task and ego-oriented goals in terms of age, year of study and the department and Tukey test was run to find out from which group the difference results.

\section{Findings}

Table 1. The Demographic Information About The Participants

\begin{tabular}{|c|c|c|}
\hline Gender & $\mathrm{N}$ & $\%$ \\
\hline Male & 224 & 59.7 \\
\hline Female & 151 & 40.3 \\
\hline Age & $\mathrm{N}$ & $\%$ \\
\hline 20 and under & 99 & 26.4 \\
\hline $21-25$ & 202 & 53.9 \\
\hline 26 and over & 74 & 19.7 \\
\hline Department & $\mathrm{N}$ & $\%$ \\
\hline Coaching & 102 & 27.2 \\
\hline Physical Education Teaching & 86 & 22.9 \\
\hline Sports Management & 94 & 25.1 \\
\hline Recreation & 93 & 24.8 \\
\hline Grades & $\mathrm{N}$ & $\%$ \\
\hline $1^{\text {st }}$ Grade & 95 & 25.3 \\
\hline $2^{\text {nd }}$ Grade & 91 & 24.3 \\
\hline $3^{\text {rd }}$ Grade & 91 & 24.3 \\
\hline $4^{\text {th }}$ Grade & 98 & 26.1 \\
\hline Field Group & $\mathrm{N}$ & $\%$ \\
\hline Team sports & 208 & 55.5 \\
\hline Individual Sports & 167 & 44.5 \\
\hline Field of Study & $\mathrm{N}$ & $\%$ \\
\hline Football & 50 & 13.3 \\
\hline Basketball & 40 & 10.7 \\
\hline Handball & 44 & 11.7 \\
\hline Volleyball & 41 & 10.9 \\
\hline Tennis & 21 & 5.6 \\
\hline Skiing & 31 & 8.3 \\
\hline Ice sports & 24 & 6.4 \\
\hline Wrestling & 20 & 5.3 \\
\hline Boxing & 23 & 6.1 \\
\hline Gymnastics & 22 & 5.9 \\
\hline Athletics & 21 & 5.6 \\
\hline Other fields & 38 & 10.1 \\
\hline Total & 375 & 100 \\
\hline
\end{tabular}

Considering the distribution of participants regarding gender, it was revealed that $59,7 \%$ of the participants consisted of male students and 40,3\% of them were comprised of female students. In terms of age, $26,4 \%$ of the students were between the ages of 17 and $21,53,9 \%$ between 21 and $25,19,7 \%$ of them were 26 or over 26 . With regards to departments, $27,2 \%$ of the total students were the ones majoring at Coaching Education, 22,9\% of them were at Physical Education Teaching, 25,1 \% at Sports Management and 24,8 \% at the Recreation Department. As for the analysis of year of study, $25,3 \%$ of the participants were studying at their $1^{\text {st }}$ grade, $24,3 \%$ of them at their $2^{\text {nd }}$ 
grade, $24,3 \%$ at the $3^{\text {rd }}$ grade and $26,1 \%$ of them were at the $4^{\text {th }}$ grade. According to the distribution of students regarding their field of study, 55,5\% of the students were competing at team sports whereas $44,5 \%$ of them were competing at individual sports.

Table 2. The Means of Task And Ego Oriented Goals Obtained from the Analysis of The Participants' Responses to 'The Task And Ego Orientation in Sport Questionnaire'

\begin{tabular}{cccccc}
\hline Sub-dimension & N & Minimum & Maximum & Mean & $\begin{array}{c}\text { Std. } \\
\text { Dev. }\end{array}$ \\
\hline Task orientation & 375 & 1 & 5 & 3,45 &, 965 \\
\hline Ego orientation & 375 & 1 & 5 & 3,36 & 1.054 \\
\hline
\end{tabular}

The analysis of Table 2 indicates that the participants had the mean scores of $(\bar{X}=3,45 \pm, 965)$ in terms of task orientation and $(\bar{X}=3,36 \pm 1,054)$ in terms of ego orientation. Based on this result, it seems that the participants of the current research had more task-orientation to reach their goals compared to ego orientation.
Table 3. The Comparison of The Participants' Views About Task and Ego-Orientation Goals in Terms of Gender

\begin{tabular}{|c|c|c|c|c|c|c|}
\hline Sub-dimension & Gender & $\mathrm{N}$ & Mean & $\begin{array}{l}\text { Std. } \\
\text { Dev. }\end{array}$ & $\mathrm{t}$ & $\mathrm{P}$ (sig.) \\
\hline \multirow{2}{*}{$\begin{array}{c}\text { Task- } \\
\text { orientation }\end{array}$} & Female & 224 & 3,40 & ,935 & \multirow{2}{*}{,- 973} & \multirow{2}{*}{,332 } \\
\hline & Male & 151 & 3,52 & 1,006 & & \\
\hline \multirow{2}{*}{$\begin{array}{c}\text { Ego- } \\
\text { orientation }\end{array}$} & Female & 223 & 3,54 & ,811 & \multirow{2}{*}{$-2,387$} & \multirow{2}{*}{, $018 *$} \\
\hline & Male & 431 & 3,23 &, 728 & & \\
\hline
\end{tabular}

*: $\mathrm{p}<0,05$

The results of the data demonstrated that there was a significant difference $(p=, 018)$ between male and female students in terms of ego- orientation goals whereas there was no statistically significant difference $(p=332)$ in terms of task- orientation goals. Accordingly, within the scope of ego-oriented category, female students $(\bar{X}=3,54 \pm, 811)$ were found to have higher ego-orientation compared to male students $(\overline{\mathrm{X}}=3,23 \pm, 728)$.

Table 4. The Comparison of The Students' Views About The Task and Ego Orientation Goals in Terms of Field of Study

\begin{tabular}{|c|c|c|c|c|c|c|}
\hline Sub-dimension & Field of study & $\mathrm{N}$ & Mean & Std. Dev. & $\mathrm{t}$ & $\mathrm{P}($ sig. $)$ \\
\hline Task-Orientation & $\begin{array}{c}\text { Team Sports } \\
\text { Individual Sports }\end{array}$ & $\begin{array}{l}208 \\
167\end{array}$ & $\begin{array}{l}3,57 \\
3,30\end{array}$ & $\begin{array}{l}9988 \\
, 928\end{array}$ & 2,258 &, $025^{*}$ \\
\hline Ego-Orientation & $\begin{array}{c}\text { Team Sports } \\
\text { Individual Sports }\end{array}$ & $\begin{array}{l}208 \\
167\end{array}$ & $\begin{array}{l}3,06 \\
3,60\end{array}$ & $\begin{array}{l}9,906 \\
1,104\end{array}$ & 4,304 &, $000 *$ \\
\hline
\end{tabular}

$*: \mathrm{p}<0,05$

According to the results of the study, there were statistically significant differences within the scope of task $(p=, 025)$ and ego orientation $(\mathrm{p}=, 000)$ dimensions $(\mathrm{p}<0,05)$. As for task-orientation, students at team sports $(\overline{\mathrm{X}}=3,54 \pm, 811)$ were found to have more task- oriented goals to realize their goals compared to students at individual sports $(\bar{X}=3,23 \pm, 728)$. In terms of ego orientation, students doing individual sports $(\overline{\mathrm{X}}=3,60 \pm, 1.104)$ were revealed to have more ego-oriented goals than students doing team sports $(\overline{\mathrm{X}}=3,06 \pm, 906)$ to realize their goals.

Table 5. The Comparison of the Students' Views About The Task And Ego Orientation Goals in Terms of Age

\begin{tabular}{|c|c|c|c|c|c|c|}
\hline Sub-dimension & Age & $\mathrm{N}$ & Mean & Std. Dev. & $\mathrm{F}$ & $\mathrm{P}($ sig. $)$ \\
\hline \multirow[b]{2}{*}{ Task-Orientation } & 20 and under & 99 & 3,49 & ,930 & \multirow[b]{2}{*}{, 151} & \multirow[b]{2}{*}{, 860} \\
\hline & $21-25$ & 202 & 3,44 & ,990 & & \\
\hline \multirow{3}{*}{ Ego- Orientation } & 20 and under & 99 & 3,38 & ,929 & \multirow{3}{*}{, 544} & \multirow{3}{*}{, 581} \\
\hline & $21-25$ & 202 & 3,32 & 1,078 & & \\
\hline & $26-30$ & 74 & 3,56 & 1,244 & & \\
\hline
\end{tabular}

$*: \mathrm{p}<0,05$

As it is indicated in Table 5 above, there were no statistically significant differences between ego $(\mathrm{p}=, 000)$ and task orientation $(\mathrm{p}=, 025)$ dimensions in terms of students' age $(\mathrm{p}>0,05)$.

Table 6. The Comparison of Participants' Views About The Task and Ego Orientation Goals in Terms of Their Departments

\begin{tabular}{|c|c|c|c|c|c|c|}
\hline Sub-dimension & Department & $\mathrm{N}$ & Mean & Std. Dev. & $\mathrm{F}$ & $\mathrm{P}$ (sig.) \\
\hline \multirow{4}{*}{ Task-Orientation } & Physical Education Teac. & 60 & 3,43 & ,803 & \multirow{4}{*}{6,792} & \multirow{4}{*}{, $000^{*}$} \\
\hline & Sports Management & 65 & 3,22 &, 838 & & \\
\hline & Coaching & 80 & 3,83 & 1,049 & & \\
\hline & Recreation & 63 & 3.23 &, 991 & & \\
\hline \multirow{4}{*}{ Ego-Orientation } & Physical Education Teac. & 60 & 3,15 & 852 & \multirow{4}{*}{6,928} & \multirow{4}{*}{, $000^{*}$} \\
\hline & Sports Management & 65 & 3,66 & 1,071 & & \\
\hline & Coaching & 80 & 3,58 & 1,119 & & \\
\hline & Recreation & 63 & 2.98 &, 981 & & \\
\hline
\end{tabular}

$*: \mathrm{p}<0,05$

According to the results of the study as demonstrated in Table 6 above, there were statistically significant differences between task $(p=, 000)$ and ego oriented $(p=, 000)$ dimensions in terms of departments that students were majoring $(p<0,05)$. 
Table 7 below displays the multiple comparisons among departments in detail.

Table 7. The Multiple Comparisons Among the Departments Regarding Participants' Views About Task And Ego Orientation Goals

\begin{tabular}{|c|c|c|c|c|}
\hline \multirow{2}{*}{ Sub-dimension } & \multicolumn{4}{|c|}{ Post Hoc (Tukey Test) } \\
\hline & \multicolumn{2}{|c|}{ Comparison } & \multirow{2}{*}{$\frac{\text { Mean Diff. }}{, 392}$} & \multirow{2}{*}{$\begin{array}{l}\text { Sig. } \\
, 070\end{array}$} \\
\hline \multirow{6}{*}{ Task Orientation } & Coaching & Phy. Edu.Teac. & & \\
\hline & & Sports Man. & 608 &, $001 *$ \\
\hline & & Recreation &, 594 &, $001 *$ \\
\hline & Sports Management & Phy. Edu.Teac. &,- 216 & 570 \\
\hline & & Coaching &,- 608 &, $001 *$ \\
\hline & & Recreation &,- 013 &, 1000 \\
\hline \multirow{9}{*}{ Ego Orientation } & Phy. Edu. Teaching & Sports Man. &,- 513 &, $027 *$ \\
\hline & & Coaching &,- 425 & ,072 \\
\hline & & Recreation &, 174 &, 780 \\
\hline & Sports Management & Phy. Edu.Teac. & ,513 &, $027 *$ \\
\hline & & Coaching &, 087 & ,955 \\
\hline & & Recreation &, 687 &, $001 *$ \\
\hline & Coaching & Phy. Edu.Teac. & ,425 &, 072 \\
\hline & & Sports Man. &,- 087 & ,955 \\
\hline & & Recreation &, 599 &, $003 *$ \\
\hline
\end{tabular}

$*: \mathrm{p}<0,05$

According to the multiple comparison results, in terms of task-orientation, there were statistically significant differences between coaching and sports management $(p=, 001)$, and between coaching and recreation $(p=, 001)$ departments $(p<0,05)$. Accordingly, students studying at coaching department $(\overline{\mathrm{X}}=3,83 \pm 1,049)$ were found to have more task-orientation compared to students majoring at sports management $(\overline{\mathrm{X}}=3,22 \pm, 838)$ and recreation $(\overline{\mathrm{X}}=3,23 \pm, 991)$ departments to realize their goals.

As for ego orientation, statistically significant differences were found between physical education teaching and sports management $(p=, 027)$, between sports management and recreation $(p=, 001)$ and coaching and recreation $(p=, 003)$ departments $(\mathrm{p}<0,05)$. Accordingly, students studying at sports management department $(\overline{\mathrm{X}}=3,66 \pm 1,071)$ were found to have higher ego orientation than the students studying at physical education teaching $(\overline{\mathrm{X}}=3,15 \pm, 852)$ and recreation $(\overline{\mathrm{X}}$ $=2,98 \pm, 981)$ departments and the students majoring at coaching education $(\overline{\mathrm{X}}=3,58 \pm 1,119)$ department were found to have higher ego orientation than the students at recreation $(\overline{\mathrm{X}}=2,98 \pm, 981)$ department.

Table 8. The Comparison of Participants' Views on Task And Ego Orientation Goals in Terms of Year of Study

\begin{tabular}{|c|c|c|c|c|c|c|}
\hline Sub-dimension & Grade & $\mathrm{N}$ & Mean & Std. Dev. & $\mathrm{F}$ & $\mathrm{P}$ (sig.) \\
\hline \multirow{4}{*}{ Task- Orientation } & $1^{\text {st }}$ grade & 91 & 3,30 & 916 & \multirow{4}{*}{1,227} & \multirow{4}{*}{,300 } \\
\hline & $2^{\text {nd }}$ grade & 70 & 3,55 & 987 & & \\
\hline & $3^{\text {rd }}$ grade & 62 & 3,49 & 971 & & \\
\hline & $4^{\text {th }}$ grade & 45 & 3.56 & 1,017 & & \\
\hline \multirow{4}{*}{ Ego- Orientation } & $1^{\text {st }}$ grade & 91 & 3,06 & ,936 & \multirow{4}{*}{4,636} & \multirow{4}{*}{, $004 *$} \\
\hline & $2^{\text {nd }}$ grade & 70 & 3,61 & 1,107 & & \\
\hline & $3^{\text {rd }}$ grade & 62 & 3,55 & 1,076 & & \\
\hline & $4^{\text {th }}$ grade & 45 & 3,32 & 1,041 & & \\
\hline
\end{tabular}

$*: \mathrm{p}<0,05$

Based on the results obtained from the analysis of the data, it was revealed that there was not a statistically significant difference in terms of task-orientation $(\mathrm{p}=, 300)$ whereas there was a significant difference in terms of ego orientation $(p=, 004)(p<0,05)$. The results of the multiple comparisons of the participants' views in terms of the year of study are displayed in Table 9.

Table 9. The Results of The Multiple Comparison of The Task And Ego Orientation Goals In Terms of Participants' Year of Study

\begin{tabular}{ccccc}
\hline \multirow{2}{*}{ Sub-dimension } & \multicolumn{4}{c}{ Post Hoc (Tukey Test) } \\
\cline { 2 - 5 } & \multicolumn{2}{c}{ Comparison } & Mean Diff. & Sig. \\
\hline \multirow{2}{*}{ Ego Orientation } & $1^{\text {st }}$ grade & $2^{\text {nd }}$ grade &,- 550 &, $005^{*}$ \\
& & $3^{\text {rd }}$ grade &,- 487 &, $023^{*}$ \\
\hline$* . p<0,05$ & & $4^{\text {th }}$ grade &,- 259 &, 513 \\
\hline
\end{tabular}

$*: \mathrm{p}<0,05$ 
According to the multiple comparison results, in terms of ego orientation, there was statistically significant difference between $1^{\text {st }}$ grade students and $2^{\text {nd }}$ grade $(\mathrm{p}=, 005)$ and $3^{\text {rd }}$ grade $(\mathrm{p}=, 023)$ students $(\mathrm{p}<0,05)$. Accordingly, it was also revealed that $1^{\text {st }}$ grade students $(\overline{\mathrm{X}}=3,06 \pm, 936)$ has more ego orientation to succeed their goals compared to $2^{\text {nd }}$ grade $(\bar{X}$ $=3,61 \pm 1,107)$ and $3^{\text {rd }}$ grade $(\bar{X}=3,55 \pm 1,076)$ students.

\section{Discussion and Conclusions}

Task and ego orientation of students who study at Faculty of Sport Science in Atatürk University has been searched while achieving their goals and the following results were obtained from the analysis of data.

The average in the sub-dimension of participants' task orientation seems to be more than average in the sub-dimesion of ego orientation. While an individual dealing with his ego, the contribution of pedagogical and psychological training on bachelor degree could be one factor that affected the results and it could account for the fact that the sub-dimension of target orientation had higher average. Particularly, if it is considered that individuals' age group that we focused, is a period that shows the transition from adolescent to adulthood, another reason could be related to the individuals management strategies to cope with general and individual targets they have regardless of being either in team sport or individual sport in trainings. Especially for the young athletes who had inadequate training; ego orientation can leave them under stress with the fear of failure on competition environments and can cause psychological problems. For this reason, it is a positive indication that our trained adolescents tend to have task orientation more than ego orientation. The finding of the study that was conducted by Arıburun and Așc1, (13) with a focus on American football players, also supports this study in that these authors also found that the average of task orientation was higher than the average of ego orientation. Similarly, Çavdarlı (14), focusing on high-school athletes and the relationship between task and ego orientation and strategy of coping with stress in sport, also found that the average of task orientation was higher than the average of ego orientation. In conclusion, these results also support the findings we obtained.

In the comparison of goal orientations, according to the gender of the participants, significant differences were observed in favor of women in the sub-dimension of ego orientation. In this regard, the reason behind this finding might be related to the fact that women feel that they have to care more about their bodies from early years contrasted with men, so they maintain these acquired habits throughout their lives (Şabaplı and Uskun, 15). For this reason, women's having more ego-orientation than men towards the way of target, seems normal. Considering this, not only the performance of opponent or the performance of teammates, but also her appearance could be a reason to have ego-orientation for them. In addition, it has been concluded that the task and ego orientation levels did not differ in terms of gender in the studies of Byoung and Gill (16), and Çavdarlı, (14). This finding contrasts with the findings we obtained. Moreover, in contrast to the findings of the present study, in the study of White and Duda (17) which focused on the relationship between ego and task oriented goals and motivation, gender, and level of sport involvement, the opposite result was found, which means that there was a significant difference between male and female students in favor of male ones regarding the task-oriented scores of students.

According to the participants of the sport branch group, statistical differences were observed as the analysis showed that students of team sports favored task orientation whereas students of individual sports favored ego-orientation. The results show that students of team sports are also such athletes who believe working more to achieve their goals. The reason is that in team sports, the targets become real with the performance of a number of people, and one's performance will affect not only himself but also his team. Thus, this result can lead the student who is competing on a team sport, have more self-responsibility and this can cause having task orientation for achieving his goals. On the other hand, in individual sports, having ego-orientation seems normal, because of the reason that these students with ego orientation work individually and compete against themselves and they keep themselves aside from their work thereby keeping themselves away from thinking of having an ability to achieve anything.

Ego orientation, which is one of the biggest factors pioneering the capabilities of these athletes on developmental age can lead qualified athletes turn into mediocre athletes. This finding has also been evidenced in the previous research (i.e. Kavussanu \& Ntoumanis, 18). In this sense, for instance, Kavussanu and Ntoumanis (18) came to the conclusion that the ego orientation negatively affected moral motivation of individuals who were in the field of study which required high contact thereby supporting our findings.

According to participants' age; although no significant differences were found in the comparison of goal orientations, it is an interesting finding of the current study that younger age groups students had more ego orientation than students between 26-30 years old. This finding may result from the fact that the students' having more sporty experience with age have more individually ego-orientation compared to inexperienced students at a young age. Because individuals who are entering a new social group are more likely to move with a group of psychology until exploring the environment, they show predisposition to task orientation. Younger students are mainly considered to be new students to school, this case can be seen as expected and normal.

According to branch of the participants, while comparing the goal orientations, it has been found significant differences about both task and ego orientation's sub-dimensions. It has been seen that in the sub-dimension of task orientation, especially students who study in the coaching department have a higher average than students in 
other departments. Because coaches are expected to be the ones who prepare students both mentally and physically while athletes are showing their best efforts; thus also, their target's being task-oriented appears to be a normal and expected result. This result can also supply that coach's education which is given in the schools is successful. It can be seen that in ego orientation's sub-dimension, students who are studying at sport management have more average. According to Walling and Duda's (9) researches show that when an athlete with high ego orientation feels his failure about the race, they become reluctant. When this is considered, having this ego by those people who are expected to manage the sport when they graduate come across in a negative light. These people at a young age should be educated by knowing that managing does not require having an ego, in contrast it is actually providing a cooperation with people by themselves and having a tendency about tasks.

As a result, with the training they received, students will shape the sport of a country, and to realize the goals of our youth precautions should be taken to cope with ego orientation and to create some individuals targeted the task orientation. For instance, to raise students' awareness of their own actions and their relationship with other people, individual seminars that aim to present a different viewpoint to the youth by enhancing the development of communication, team and leadership could be organized to come up with the challenges the youth experience. With this, our youth who study at faculty of sport science will know the privilege of working and do their bests and they will contribute to the development of Turkish sports.

This research is limited to the investigation of the students with an age range between 30 and under 20 majoring at four different Departments at the Faculty of Sports Sciences at Atatürk University, that were, the Departments of Physical Education Teaching, Sports Management, Coaching and Recreation at two fields of study, that are, Team Sports or Individual Sports with a range from the $1^{\text {st }}$ year of study to $4^{\text {th }}$ year of study. More specifically, the current study limits the scope of this research to a total of 375 students at the Faculty of Atatürk University to have an insight on their ego and task oriented goals and to shed a light on the differences and similarities among students' views about task and ego oriented goals in terms of their gender, age, field of study, department and grade.

\section{REFERENCES}

[1] Duda, J. L. "Goal perspectives, participation and persistence in sport”, International Journal of Sport Psychology. 1989; 20, $42-56$.

[2] Toros, T. ve Yetim, Ü. Sporda Görev ve Ego Yönelimleri Ölçeğinin Türk Sporcuları İçin Uyarlama Ön Çalışması. International Sports Sciences Congress. 2000, 11-13 May, İstanbul.
[3] Toros, T. Elit ve Elit Olamayan Erkek Basketbolcularda Hedef Yönelimi, Güdüsel (Motivasyonel)İklim ve Hedeflerin Özgünlük Güçlük Derecesi Özelliklerinin Yaşam Doyumuna Etkisi. Mersin University, Institute of Medical Sciences, Mersin. 2001.

[4] Nicholls, Cheung, Lauer, Pastashnick. İndivindiual Differences in Academic Motivation: Perceived Ability, Goals, Beliefs, and Values. Learning and Individual Differences. 1989; 1, 63-84.

[5] Duda, J.L., Nichollos, J.G. Dimensions of Achievement Motivation in Schoolwork and Sport. Journal of Educational Psychology. 1992; 84,290-299

[6] Nicholls, Cobb, Yackel, Wood and Wheatley. Students' theories about mathematics and their mathematical Knowledge: Mutiple Dimensiojns Of Assessment. In G. Kulm (Ed) Journal For Research in Mathematics Education. $1990 ; 21.109-122$.

[7] Stephens and Bredemier. Moral Atmosphere and Judgements About Agression in Girls' Soccer: Relationship Among Moral and Motivation Variables. Journal of Sport and Exercise Psychology. 1995;18, 158-173.

[8] Toros, T. \& Koruç, Z. Hedef Yönelimleri ve Algılanan Motivasyonel İklim Arasındaki İlişki (Liseli Erkek Voleybolcular Üzerine Bir Çalışma). Hacettepe Spor Bilimleri Dergisi. 2005; 16 (3), 135-145.

[9] Walling, M. D., \& Duda, J. L., . Goals And Their Associations With Beliefs About Success in the Perceptions of the Purpose of Physical Education. Journal of Teaching in Physical Education. 1995; 14, 140-156.

[10] Duda, J. L. Motivation in sport setting: A goal perspective approach. In Roberts, G. C. (Eds.), Motivation in sport and exercise (pp.57-91). Champaign, Illinois: Human Kinetics; 1992.

[11] Boyd, M.P. The effects of participation orientation and success-failure on post-competitive affect in young athletes. Yayınlanmamış doktora tezi, University of Southern California. 1990

[12] Duda, J.L. \& Chi, L. The effect of task and ego involving conditions on perceived competence and causal attributions in basketball. Makale Uygulamalı Spor Psikoloji Birliği, University of Washington, Seattle, WA, Eylül'de sunulmuştur; 1989.

[13] Arıburun, B. ve Aşçı, H. Amerikan Futbolu Oyuncularında Hedef Yönelimi ve Algılanan Güdüsel İklim. The Journal of Sportmetre Physical Training and Sports Sciences. 2005; III (3). 111-114

[14] Çavdarlı, Ş. Liseli Sporcularda Görev ve Ego Yönelimleri ile Sporda Stresle Başa Çıkma Stratejileri Arasındaki İlişki, Beden Eğitimi ve Spor Anabilim Dalı, Unpublished MA Thesis, Mersin University, Institute of Education Sciences, Mersin; 2013.

[15] Şabaplı ve Uskun. Lise Öğrencilerinin Beden Algıları ile Yeme Tutumları Arasındaki İlişki. TAF Preventive Medicine Bulletin. 2013; 12 (5), p519-528. 10, Turkey.

[16] Byoung, J.K. and Gill, D.L. A cross-cultural extension of goal perspective theory to Korean youth sport. Journal of Sport \& Exercise Psychology. 1997; 19, 142-155.

[17] White, S. A. and Duda, J. L. The relationship of gender, level 
of sport involvement, and participation motivation to task and ego orientation, International Journal of Sport Psychology. $1994 ; 25,1,4-18$.
[18] Kavussanu, M. and Ntoumanis, N. Participation in Sport and Moral Functioning: Does Ego Orientation Mediate Their Relationship? Journal of Sport and Exercise Psychology, 2003; 25, 501-518.. Human Kinetics Publishers, Inc.USA 